\title{
Can the UK emulate the South Korean approach to covid-19?
}

\author{
Not yet, and perhaps not ever
}

\author{
Azeem Majeed professor of public health ${ }^{1}$, Yongseok Seo professor ${ }^{2}$, Kyungmoo Heo doctoral \\ student $^{2}$, Daejoong Lee doctoral student ${ }^{2}$
}

${ }^{1}$ Department of Primary Care and Public Health, School of Public Health, Imperial College London, London, UK; ${ }^{2}$ Moon Soul Graduate School of Future Strategy, Korea Advanced Institute of Science and Technology, Daejeon, South Korea

On 29 February 2020, South Korea, a country of similar population size to England, recorded 909 news cases of covid-19. At the time, this was one of the worst covid-19 outbreaks outside Wuhan in China, the origin of the global pandemic. ${ }^{1}$ On the same day, only 55 new cases of covid-19 were recorded in England.

By mid-May, despite several weeks of "lockdown" and a decline in numbers since the peak in April 2020, the UK was still recording over 3000 cases each day; this compared with fewer than 30 cases a day in South Korea. Furthermore, the UK has so far recorded over 36000 deaths from covid-19 compared with under 300 in South Korea. ${ }^{2}$ Why has the impact of covid-19 in the two countries varied so much?

The key difference between the two countries was that South Korea rapidly adopted a "test, trace, isolate, and treat" strategy. People with suspected disease were tested, contacts identified, strict isolation enforced, and free treatment given to those infected, with compensation for people who had to self-isolate. ${ }^{3}$ The UK put in place limited testing early on in the pandemic and then abandoned contact tracing and community testing in March. This policy probably contributed to the rapid increase in the number of covid-19 cases and deaths. South Korea expanded its testing capacity more quickly than the UK in the early part of its outbreak, ensuring it had sufficient tests to implement its testing and tracing policy.

Information technology also had a key role in South Korea's strategy to contain covid-19. ${ }^{3}$ Mobile phones were used from early on in the pandemic to support rapid testing and contact tracing. The UK, by contrast, has been a late adopter of mobile phone technology, with its contact tracing app currently being piloted in the Isle of Wight and no date yet set for its nationwide availability.

Mobile phones were also used to disseminate emergency information, such as location of "infection hotspots," to the public in South Korea. Numbers of positive test results and infection rates were made available on local and national government websites together with the location (but not identity) of confirmed cases. Covid-19 testing and a 14 day quarantine period became mandatory for travellers arriving in South Korea from May, as a high proportion of newly confirmed cases came from overseas. ${ }^{45}$

South Korea moved early to remote working wherever possible. Schools were closed early in the outbreak and remote learning put in place. The government encouraged widespread wearing of face masks, and it is now compulsory in many locations, such as on the public metro system. To ensure adequate supplies, the Korean government took control of the manufacture of face masks and implemented mandatory public procurement measures. ${ }^{6}$

Telemonitoring services were established for patients who were unwell in the community, and swab testing was accelerated through innovations such as positive pressure testing booths. The closed positive pressure environment protected testers, who only had to replace their gloves between patients, cutting swabbing times to around one minute each. ${ }^{37}$ Finally, South Korea's response was more urgent than in the UK, driven by experience with other viral outbreaks such as the Middle East respiratory syndrome (MERS) in 2015. ${ }^{8}$

\section{Lessons for the UK}

What can the UK learn from South Korea's approach? The UK government relied heavily on mathematical models and adopted policy led by science. ${ }^{910}$ This resulted in delays in implementing potentially useful interventions such as the public wearing of face masks because conclusive evidence of benefit wasn't available. ${ }^{11}$ South Korea was quicker to base decisions on the precautionary principle when the evidence was unclear. ${ }^{12}$

Another lesson is the need to enforce isolation for people with covid-19. In South Korea, isolation is monitored through the compulsory use of a mobile phone app and includes financial support for families. ${ }^{13}$ Violation of quarantine regulations is a criminal offence and can result in a fine of up to 10 million won 
(£6600; €7400; \$8100) or a year in prison. ${ }^{3}$ Enforcement of isolation helped South Korea avoid full lockdown, and society is now starting to return to normal, although the recent outbreak linked to night clubs suggests such venues may need to remain closed..$^{14}$

The UK government's proposed testing and contact tracing strategy does not match the South Korean approach. Capacity is currently insufficient to test all suspected cases, contacts, health and care workers, other key workers, and vulnerable groups such as people in care homes and prisons. An effective contact tracing system is also lacking. ${ }^{15}$ On 20 May, Boris Johnson told parliament that a UK-wide tracing system would be in place by 1 June, ${ }^{16}$ but it is still unclear whether this can be achieved, even with a combination of technological and manual tracing methods.

Integration with local primary care and public health teams is another missing element along with enforceable isolation for cases and contacts. ${ }^{17}$ Only when all essential components of a test, trace, and isolate system are in place and working well can we say that the UK is following South Korea's successful approach to controlling covid-19 and not risking a second wave of infections when lifting lockdown. ${ }^{18}$

Competing interests: We have read and understood BMJ policy on declaration of interests and declare the following interests: $\mathrm{DL}$ is the director of development finance at the finance ministry of the Government of South Korea.

Provenance and peer review: Commissioned; not externally peer reviewed.

1 Shim E, Tariq A, Choi W, Lee Y, Chowell G. Transmission potential and severity of COVID-19 in South Korea. Int $J$ Infect Dis 2020;93:339-44.

10.1016/j.jij. 2020.03 .03132198088

2 Worldometer. Covid-19 coronavirus pandemic. https://www.worldometers.info/coronavirus/
3 Government of the Republic of Korea. Flattening the curve on covid-19: how Korea responded to a pandemic using ICT. 2020. http://overseas.mofa.go.kr/gr-en/brd/m 6940/ view.do?seq=761548

4 Korean Government's response system. Preventing the inflow and spread of the infectious disease. http://ncov.mohw.go.kr/en/baroView.do?brdld=11\&brdGubun=111\&dataGubun=\& ncvContSeq=\&contSeq=\&board $\_$id $=$

5 Korea Centers for Disease Control \& Prevention. The updates on covid-19 in Korea as of 08 May 2020. https://www.cdc.go.kr/board/board.es?mid=a30402000000\&bid=0030\& act=view\&list_no $=367177 \&$ tag $=\&$ nPage $=3$

6 Kim ET. How South Korea solved its face mask shortage. New York Times, 2020 Apr 1. https://www.nytimes.com/2020/04/01/opinion/covid-face-mask-shortage.html

7 Choi S, Han C, Lee J, Kim SI, Kim IB. Innovative screening tests for COVID-19 in South Korea. Clin Exp Emerg Med 2020. 10.15441/ceem.20.032 32295319

8 Scally G, Jacobson B, Abbasi K. The UK's public health response to covid-19. BM 2020;369:m1932. 10.1136/bmj.m1932 32414712

9 Kelly EU. K's chief science advisers say response to COVID-19 will evolve as data comes in. Science Business 2020 Mar 19.https://sciencebusiness.net/covid-19/news/uks-chiefscience-advisers-say-response-covid-19-will-evolve-data-comes

10 Scoones I. Science, uncertainty and the COVID-19 response. https://www.ids.ac.uk opinions/science-uncertainty-and-the-covid-19-response/

11 Greenhalgh T, Schmid MB, Czypionka T, Bassler D, Gruer L. Face masks for the public during the covid-19 crisis. BMJ 2020;369:m1435. 10.1136/bmj.m1435 32273267

12 Cho HW. Effectiveness for the response to covid-19: The MERS outbreak containment procedures. Osong Public Health Res Perspect 2020;11:1-2. 10.24171/j.phrp.2020.11.1.0132149035

13 Lee S. Fighting COVID 19-legal powers and risks: South Korea. VerfBlog, 25 Mar 2020. https://verfassungsblog.de/fighting-covid-19-legal-powers-and-risks-south-korea/

14 Gunia A. What South Korea's nightclub coronavirus outbreak can teach other countries as they reopen. Time 2020 May 12. https://time.com/5834991/south-korea-coronavirusnightclubs/

15 Pollock AM, Roderick P, Cheng KK, Pankhania B. Covid-19: why is the UK government ignoring WHO's advice?BMJ 2020;368:m1284. 10.1136/bmj.m1284 32229543

16 Proctor K. Boris Johnson pledges UK-wide coronavirus tracing by 1 June. Guardian2020 May 20. https://www.theguardian.com/politics/2020/may/20/boris-johnson-pledges-englandwide-coronavirus-tracing-by-1-june

17 Majeed A. The primary care response to covid-19 in England's National Health Service. $J R$ Soc Med (forthcoming).

18 Coronavirus: Time running out on track and trace, NHS leaders warn. BBC News 2020 May 21. https://www.bbc.co.uk/news/uk-52748564

This article is made freely available for use in accordance with BMJ's website terms and conditions for the duration of the covid-19 pandemic or until otherwise determined by BMJ. You may use, download and print the article for any lawful, non-commercial purpose (including text and data mining) provided that all copyright notices and trade marks are retained.

https://bmj.com/coronavirus/usage 